Horizons in Physical Geography 
Also Available from Macmillan Education

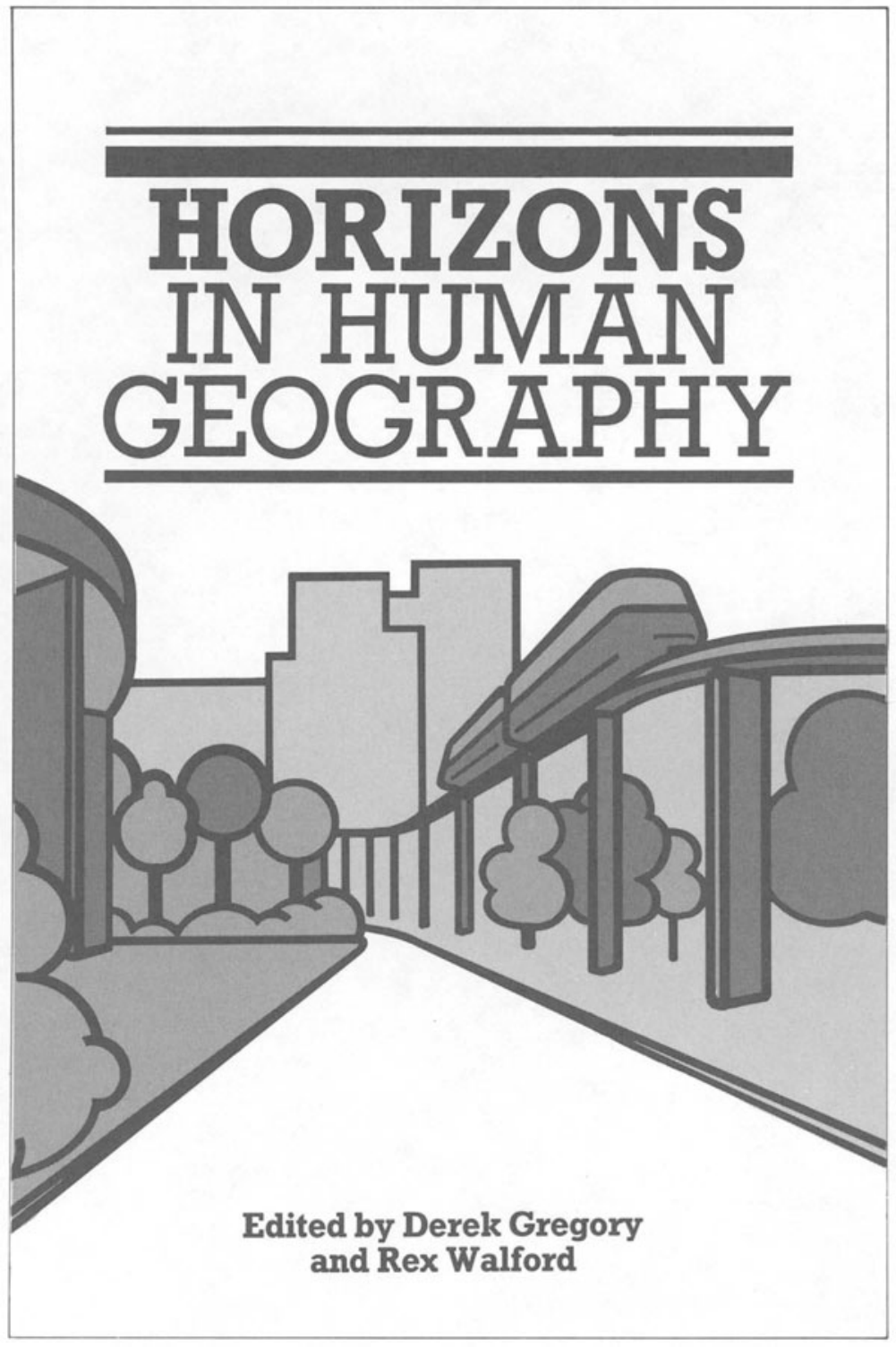

Publication Autumn 1988

ISBN 978-0-333-39611-7 HC ISBN 978-0-333-39612-4 PR 


\section{Horizons in Physical Geography}

Edited by

Michael J. Clark, Kenneth J. Gregory and Angela M. Gurnell

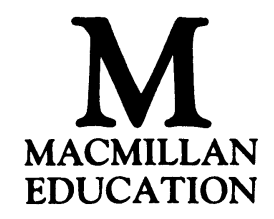


Introduction, Chapter 5.4, selection and editorial matter (C) Michael J. Clark, Kenneth J. Gregory and Angela M. Gurnell 1987

Individual chapters (C) Frank Oldfield, John B. Thornes, Michael J. Kirby, John R. G. Townshend, W. Brian Whalley, D. E. Walling, B. W. Atkinson, Clifford Embleton, William Ritchie, I. G. Simmons, Stephen T. Trudgill, John Lewin, David E. Sugden, Jack D. Ives, Andrew S. Goudie, Ronald U. Cooke, Vincent Gardiner, John Whittow, Andrew Warren, Edmund C. Penning-Rowsell, Malcolm Newson, Roger G. Barry, Keith M. Clayton, Richard J. Chorley 1987

All rights are reserved. No reproduction, copy or transmission of this publication may be made without written permission.

No paragraph of this publication may be reproduced, copied or transmitted save with written permission or in accordance with the provisions of the Copyright Act 1956 (as amended), or under the terms of any licence permitting limited copying issued by the Copyright Licensing Agency, 33-4 Alfred Place, London WC1E 7DP.

Any person who does any unauthorised act in relation to this publication may be liable to criminal prosecution and civil claims for damages.

First published 1987

Published by

MACMILLAN EDUCATION LTD

Houndmills, Basingstoke, Hampshire RG21 2XS

and London

Companies and representatives

throughout the world

Typeset in Great Britain by

TecSet Limited, Wallington, Surrey

British Library Cataloguing in Publication Data

Horizons in physical geography.

1. Physical geography

I. Clark, Michael J. II. Gregory, Kenneth J.

III. Gurnell, Angela M.

910'.02 GB54.5

ISBN 978-0-333-39610-0 978-1-349-18944-1 (eBook)

DOI 10.1007/978-1-349-18944-1 


\section{Contents}

Preface $\quad$ xi

Acknowledgements xiii

Notes on the Contributors xiv

Introduction: Change and Continuity in Physical Geography

Michael J. Clark, Kenneth J. Gregory, Angela M. Gurnell 1

An uneasy alliance? 1

Exploration in a technical age: new scales - new dimensions 3

Evolving priorities: new worlds - new environments 3

An evolving philosophy 4

\section{PART I THE SEARCH FOR ORDER}

\section{SECTION 1 FRAMEWORKS FOR INVESTIGATION}

\subsection{The Future of the Past - A Perspective on Palaeoenvironmental}

Study

Frank Oldfield

Lakes and bogs - a context for palaeoenvironmental

evidence

Dating the recent past 13

Reconstructing recent ecosystem changes $\quad 15$

New methods of palaeoenvironmental reconstruction 16

$\begin{array}{ll}\text { Case studies } & 17\end{array}$

$\begin{array}{ll}\text { Conclusions } & 23\end{array}$

1.2 Environmental Systems - Patterns, Processes and Evolution

John B. Thornes

An example: river channel systems $\quad 28$

Dynamical systems $\quad 32$

Implications and prospects $\quad 43$

$\begin{array}{ll}\text { Conclusions } & 45\end{array}$

\subsection{Models in Physical Geography}

Michael J. Kirkby 47

What is a model? $\quad 47$

The relationship between models and case studies $\quad 47$ 
The roles of modelling 51

Tools of model-building 54

Styles of quantitative model $\quad 56$

The limitations and potential of modelling $\quad 59$

\subsection{Remote Sensing - Global and Local Views}

John R. G. Townshend

Widening the spectral view $\quad 62$

Improving the spatial detail $\quad 69$

Improving the temporal frequencies $\quad 75$

Extracting information from remotely sensed data 77

Conclusions $\quad 83$

1.5 Mechanisms, Materials and Classification in Geomorphological Explanation

W. Brian Whalley $\quad 86$

Mechanisms and processes $\quad 88$

Description and explanation $\quad 89$

The simplification of geomorphology? 90

Properties of materials $\quad 93$

Classification and geography $\quad 95$

Scales of examination $\quad 97$

$\begin{array}{lr}\text { Conclusions } & 102\end{array}$

\section{SECTION 2 A ROLE FOR ENVIRONMENTAL PROCESS}

2.1 Hydrological and Fluvial Processes: Revolution and Evolution D. E.Walling 106

Changes afoot $\quad 106$

Current status 111

$\begin{array}{ll}\text { The future } & 117\end{array}$

2.2 Atmospheric Processes - Global and Local

B. W. Atkinson 121

Some basic properties $\quad 122$

New observational techniques 123

New analytical techniques $\quad 125$

New forms and processes $\quad 126$

$\begin{array}{ll}\text { Conclusions } & 132\end{array}$

2.3 Geomorphological Processes in Cold Environments

Clifford Embleton $\quad 134$

Process domains $\quad 135$

Glaciological processes $\quad 135$

$\begin{array}{ll}\text { Glacial geomorphological processes } & 140\end{array}$ 
Geocryological processes

Conclusions

2.4 Theory and Reality in Coastal Geomorphology William Ritchie

The scope of coastal geomorphology 151

Two general models 153

The coast in three dimensions: the tidal factor 155

Coastal cycles and frequency of events 160

$\begin{array}{ll}\text { Problems of data acquisition } & 161\end{array}$

The reality and practice of coastal geomorphology 162

2.5 Lilies and Peacocks: a View of Biogeography

I. G. Simmons 165

Context and definition $\quad 165$

Process in biogeography 166

The historicity of manipulations 168

$\begin{array}{ll}\text { Consequences and conclusions } & 174\end{array}$

2.6 Soil Processes and their Significance

Stephen T. Trudgill 181

Soil formation and development 183

Spatial variability $\quad 185$

Soil systems $\quad 186$

Some interdisciplinary links $\quad 187$

Soils and agriculture 191

Soil management and the environment 193

Concluding perspective: horizons in soil study 194

\section{PART II EXPLANATION AND CONTROL}

SECTION 3 ENVIRONMENTAL IMPACT AND CHANGE: A GEOGRAPHICAL VIEW

3.1 Stable and Unstable Environments - The Example of the

Temperate Zone

John Lewin

Initial considerations: toward actualistic environmental

modelling

Slopes, rivers and floodplains in temperate environments 203

Global tectonics and morphology 208

On the horizon 
NEW PHYSICAL FRONTIERS: INSTABILITY AND CHANGE

\subsection{The Polar and Glacial World}

David E. Sugden

Initiation of the Greenland and Antarctic ice-sheets 217

Oscillations of polar ice-sheets $\quad 220$

Some methodological issues $\quad 226$

Priorities and logistics $\quad 229$

Conclusions $\quad 230$

\subsection{The Mountain Lands}

Jack D. Ives

Definition of the mountain zone 234

Progress in mountain geomorphology 1960-85 234

Natural hazards and mountain hazards mapping 243

Conclusions 247

3.4 Change and Instability in the Desert Environment

Andrew S. Goudie

Aspects of variability 250

Change and human impact 257

Conclusions 266

SECTION 4 MANAGEMENT OF THE PHYSICAL ENVIRONMENT

\subsection{Geomorphology and Environmental Management}

Ronald U. Cooke

The rise of geomorphology in environmental management 272

The work of applied geomorphologists $\quad 275$

A look forward $\quad 284$

\section{FOCUSES FOR ENVIRONMENTAL MANAGEMENT}

\subsection{Evaluating Environmental Potential}

Vincent Gardiner

Dilemmas in evaluating environmental potential 292

Methods for evaluating environmental components 293

Integrated evaluation of environmental potential 302

Future directions and prospects 303

\subsection{Natural Hazards - Adjustment and Mitigation}


The development of hazard study

Human perception and response

Mitigation and alleviation measures

4.4 Geography and Conservation: The Application of Ideas About People and Environment Andrew Warren

Science, ideologies and motives

Environmental constraints

Values, morals and reasons

Environments and cultures: two ways of valuing the same environment

Conclusions

ENVIRONMENT, MANAGEMENT AND THE FUTURE OF PHYSICAL GEOGRAPHY

4.5 Planning and Management: Physical Geography and Political

Processes

Edmund C. Penning-Rowsell

The context of applications in physical geography

Individuals and social structures: the case of flood hazard alleviation

Physical 'problems' and political decisions: two examples

Conclusions

4.6 From Description to Prescription: Measurements and

Management

Malcolm Newson

Towards professionalism

Aspects of management

Common themes in applied studies

Prediction, prescription and professionalism

\section{PART III PERSPECTIVES ON PHYSICAL GEOGRAPHY}

5.1 Perspectives on the Atmosphere

Roger G. Barry

\subsection{Perspectives on the Geosphere}

Keith M. Clayton

5.3 Perspectives on the Hydrosphere

Richard J. Chorley 
5.4 Physical Geography: Diversity and Unity

Michael J. Clark, Kenneth J. Gregory, Angela M. Gurnell

Index 


\section{Preface}

It is now more than twenty years since Richard Chorley and Peter Haggett compiled their path-breaking survey of Frontiers in Geographical Teaching (1965), which, together with Models in Geography published just two years later (1967), did so much to consolidate the foundations of what had come to be called the 'New Geography'. The intervening two decades have seen further (and, on occasion, dramatically different) developments in the discipline. Indeed, one of the lasting contributions of both Frontiers and Models was to recognise and welcome change as the very life-blood of intellectual inquiry. To be sure, many of these changes collided awkwardly with individuals, institutions and even governments which, in their various ways, sought to impose some sort of stability or direction - a semblance of order - on the shifting kaleidoscope of discovery and debate. But there can be no doubt that since 1965 geography has continued (and is continuing) to change, and Horizons in Human Geography and Horizons in Physical Geography are intended to introduce some of the most exciting challenges of the contemporary subject to a wider audience. Like Frontiers, the Horizons volumes are directed primarily at teachers, although we naturally hope for a wider readership. We regard geography in the schools and geography in the colleges, polytechnics and universities as parts of a corporate project. Their aims and audiences are of course different, and it would be quite wrong to think of school geography as no more than a conveyor belt into further and higher education. But each has a measure of responsibility for the other, and we hope that the contributions to these volumes will help to promote a sustained dialogue between them.

For all that they have in common, however, these two books depart from the original volumes in a number of ways which we want to signpost in advance. In the first place, we have accepted that geography is a bipolar subject - like so many others - and we have therefore divided the contributions into human geography and physical geography. Some will no doubt regard this as a betrayal of the integrity of the subject, others as a mere convenience which reflects little more than the conventions of teaching and research. We see it, rather, as a way of drawing attention to the substantial differences between a human geography modelled on the humanities and the social sciences and a physical geography modelled on the natural sciences. This is not to say that there are no contacts or connections between the two, 
and we have attempted to chart some of the most important in both volumes. But we believe that the differences which remain - between a human geography which, as one of its central tasks, has to make sense of a 'preinterpreted' world which is intrinsically meaningful to the people who live within it, and a physical geography which seeks to explain a shifting, changing but none the less 'object' world - are of vital significance to the future development of both human and physical geographies. That some of the most exciting developments in geography lie now, as they have for the past century, at the point where these two worlds and their different intellectual traditions intersect stengthens rather than weakens the case for a bipolar approach. The integrities of each must be respected, not erased by the casual translation of one into the other.

In the second place, and in addition to these differences between the two volumes, there are differences within them. Neither has been conceived as a manifesto for some new orthodoxy. Each essay is of its author's making, and although we have drawn contributors' attention to cross-references and cross-connections, we have deliberately made no attempt to ensure uniformity of viewpoint. Common threads do emerge, but these have not been imposed by editorial design. One of the hall-marks of geography today, and a sign of its maturity, is its diversity. For this reason we have not aimed at an encyclopaedic coverage, but have preferred instead to identify a series of key topics and themes to be approached by different authors from different perspectives. These themes, and the structures that they create, are of course editorial artifacts, and should not be taken to represent a fixed or self-evident map of geography's intellectual landscape. It is, after all, a characteristic of a kaleidoscope that its component parts can build an infinite number of different but often equally satisfying patterns. The result, we believe, is thought-provoking testimony to the continuing power of that deep-rooted 'concern' for geography which Haggett and Chorley accentuated in the 1960 s, and of their own reminder that 'to stand still is to retreat'.

Michael Clark

Kenneth Gregory

Derek Gregory

Angela Gurnell

Rex Walford 


\section{Acknowledgements}

The author and publishers wish to thank the following who have kindly given permission for the use of copyright material: Australian Geographical Studies for Fig. 1 from 'Any Milleniums Today, Lady? The Geographic Bandwaggon Parade' by J. N. Jennings 1973 Vol. 11; Department of Geography, University of Guelph for Fig. 1 from 'Research in polar and alpine geomorphology' by M. M. Miller, 3rd Guelph Symposium, 1973, Geo Books (Geo Abstracts Ltd); Gebruder Borntraeger for Figs. 2, 12 from 'Modelling cliff development in South Wales' by M. J. Kirby, Zeitschrift für Geomorphologie, 28, 4; D. K. Jones for Fig. 9 from TransInst. Brit. Geogr. NS 8, 1983, Institute of British Geographers; J. Haans and G. Westerveldt for Fig. 12 from 'The application of soil survey in the Netherlands', Geoderma, 1970, Elsevier Science Publishers B. V.; Hessischen Landesamt fur Bodenforschung for maps I-IV from Die Standortkartierung der Hessischen Weinbaugebiete by $\mathrm{H}$. Zakosek, W. Kreutz, W. Bauer, H. Becker and E. Schroder (1967); J. D. Ives for Fig. 7 and Table 2 from 'The Nature of Mountain Geomorphology' by D. Barsch and N. Caine, Mountain Research and Development, 4(4) 1984; Ministry of Agriculture, Fisheries and Food for extracts from Agriculturual Land Classification Maps, Sheets 157-8, (C) British Crown Copyright; Quaternary Research Association for Fig 1. from 'A classification of till' by G. S. Boulton, Quaternary Newsletter No. 31, May 1980; Royal Meteorological Society for Figs. 1, 3 from 'Visual presentation of weather forecasting for personal comfort' by A. Auliciems and F. K. Hare, Weather, 28, 1973; W. R. D. Sewell for figure 'Adjustment to the flood hazard'; Soil Survey of England and Wales for extracts from Soil Survey Map, Sheet 253, 1: 63 360; J. R. G. Townshend for Figs. 2.1, 2.6 from Terrain Analysis and Remote Sensing, George Allen \& Unwin; M. Toshino for Fig. 2.1 from Climate in a Small Scale, University of Tokyo Press (1961). Every effort has been made to trace all the copyright-holders, but if any have been inadvertently overlooked the publishers will be pleased to make the necessary arrangement at the first opportunity. 


\section{Notes on the Contributers}

Atkinson, B. W. Professor of Geography, Queen Mary College, University of London

Barry, Roger G. Professor of Geography, University of Colorado, USA Chorley, Richard J. Professor of Geography, University of Cambridge

Clark, Michael J. Senior lecturer in Geography, University of Southampton

Clayton, Keith M. Professor of Environmental Sciences, University of East Anglia

Cooke, Ronald U. Professor of Geography, University College, University of London

Embleton, Clifford Professor of Geography, King's College, University of London

Gardiner, Vincent Lecturer in Geography, University of Leicester Goudie, Andrew S. Professor of Geography, University of Oxford

Gregory, Kenneth J. Professor of Geography, University of Southampton

Gurnell, Angela M. Senior lecturer in Geography, University of Southampton

Ives, Jack D. Professor of Geography, University of Colorado, USA

Kirkby, Michael J. Professor of Physical Geography, University of Leeds

Lewin, John Professor of Geography, University College of Wales, Aberystwyth

Newson, Malcolm D. Professor of Physical Geography, University of Newcastle upon Tyne

Oldfield, Frank John Rankin Professor of Geography, University of Liverpool

Penning-Rowsell, Edmund C. Professor of Geography and Planning, Middlesex Polytechnic

Ritchie, William Professor of Geography, University of Aberdeen

Simmons, Ian G. Professor of Geography, University of Durham

Sugden, David E. Professor of Geography, University of Edinburgh

Thornes, John B. Professor of Geography, University of Bristol

Townshend, John R. G. Reader in Geography, University of Reading

Trudgill, Stephen T. Senior lecturer in Geography, University of Sheffield

Walling, Desmond Professor of Physical Geography, University of Exeter

Warren, Andrew Reader in Geography, University College, University of London

Whalley, W. Brian Reader in Geography, Queen's University of Belfast Whittow, John Senior lecturer in Geography, University of Reading 